\title{
ANALYSIS OF THE TAIL STRUCTURES OF COMET 1P/HALLEY 1910 II
}

\section{ANÁLISE DAS ESTRUTURAS CAUDAIS DO COMETA 1P/HALLEY 1910 II}

\section{Marcos Rincon Voelzke ${ }^{1}$}

ABSTRACT: For the purpose of identifying, measuring, and correlating the morphological structures along the plasma tail of 1P/Halley, 886 images from September 1909 to May 1911 are analysed. These images are from the Atlas of Comet Halley 1910 II (DONN; RAHE; BRANDT, 1986).

Keywords: comets; Comet 1P/Halley 1910 II; disconnection events in comets; interaction with solar wind.

RESUMO: Com a finalidade de identificar, medir e correlacionar as estruturas morfológicas ao longo da cauda de plasma do 1P/Halley, 886 imagens, a partir de setembro de 1909 até maio de 1911, foram analisadas. Essas imagens são provenientes do Atlas do Cometa Halley 1910 II (DONN; RAHE; BRANDT, 1986).

Palavras-chave: cometas; Comet 1P/Halley 1910 II; eventos de desconexão em cometas; interação com o vento solar.

\footnotetext{
1 Universidade Cruzeiro do Sul - UNICSUL / Programa de Pós-graduação em Ensino de Ciências e Matemática. Grupo de
} Elementos e Metodologia do Ensino de Física e Matemática. E-mail: mrvoelzke@hotmail.com. 


\section{INTRODUCTION}

This work is based on a systematic analysis of images of $1 \mathrm{P} /$ Halley comet collected during its penultimate approach.

The entire database consists of 1006 images of the comet observed from 11 September 1909 to 30 May 1911.

These images were usually obtained with telescopes of large angular field, showing specially the tail morphology.

The present research basically characterised, identified, classified and measured some of the tail structures of comet 1P/Halley like disconnection events (DEs) (BRANDT et al., 1992; VOELZKE; MATSUURA, 2000; VOELZKE, 2002, 2005), wavy structures (YI et al., 1998) along the main and secondary tails, Swan-like tails (HYDER; BRANDT; ROOSEN, 1974; JOCKERS, 1985), knots (VOELZKE, 1996; VOELZKE; SCHLOSSER; SCHMIDT-KAER, 1997), shells (SCHULZ; SCHLOSSER, 1989; SCHULZ; A'HEARN; SAMARASINHA, 1992) and solitary waves (solitons) (ROBERTS, 1985; TOMITA; SAITO; MINAMI, 1987). This work reports essentially the observational properties of the tail structures in comet 1P/Halley $1910 \mathrm{II}$.

\section{OBJECTIVES \& DATA}

For the purpose of identifying, measuring and correlating the morphological structures along the plasma tail of $1 \mathrm{P} / \mathrm{Halley}$ 886 images from September 1909 to May 1911 are analysed.

These images are from the Atlas of Comet Halley 1910 II (DONN; RAHE; BRANDT, 1986). They were obtained through original photographic plates or good film copies of originals from the observatories and also through reproduced copies of images from journals.

Image Analysis

A systematic visual analysis revealed:

- 304 wavy structures along the main tail, which corresponds to $34.31 \%$ of all analysed images

- 164 wavy structures along the secondary tails (18.51\%)

- 41 solitary waves (solitons $=$ kinks) (4.63\%)

- 13 Swan-like tails (1.47\%)

- 26 disconnection events (DEs) $(2.93 \%)$

- 166 knots (regions of higher density of matter) (18.74\%)

- 6 shells $(0.68 \%)$

In general, it is possible to associate the occurrence of a DE and/or a Swan-Tail with the occurrence of a knot, but the last one may occur independently.

It is also possible to say that the solitons occur in association with the wavy structures, but the reverse is not true.

The mean value of the corrected wavelength $\lambda c$ measured in 70 different wavy structures is equal to:

$$
\lambda c=(1,7 \pm 0,1) \times 10^{6} \mathrm{~km}
$$

And the mean amplitude $A$ of the wave (measured in the same 70 wavy structures) is equal to:

$$
A=(1,4 \pm 0,1) \times 10^{5} \mathrm{~km}
$$

The average value of the corrected velocities Vkc of the knots measured in 36 
different images is equal to:

$$
\mathrm{Vkc}=(128 \pm 12) \mathrm{km} / \mathrm{s}
$$

The 26 DEs documented in 26 different images allowed the derivation of two onsets of DEs, i.e., the time when the comet supposedly crossed a frontier between magnetic sectors of the solar wind (BRANDT; SNOW, 2000).

Both onsets of DEs were determined after the perihelion passage with an average of the corrected velocities $\mathrm{Vc}$ equal to:

$$
\mathrm{Vc}=(57 \pm 15) \mathrm{km} / \mathrm{s}
$$

The mean value of the corrected cometocentric phase velocity Vpc measured in 20 different wavy structures is equal to:

$$
\mathrm{Vpc}=(168 \pm 28) \mathrm{km} / \mathrm{s}
$$

\section{CONCLUSIONS}

The analysis of the 886 selected images showed that, in general, the DEs and/or the Swan-Tails occur in association with the knots, but the knots may occur independently, and also it is possible to say that the solitons occur in association with the wavy structures, but the reverse is not true.

The plasma of an individual DE is assumed to move away from the cometary nucleus most of time with a constant velocity. Such a velocity however varies broadly from one DE to another. In the all 886 analysed images, 26 displayed DEs. The 26 observed DEs were related to two onsets of DEs.

The amplituede $A$ as well as the corrected wavelength $\lambda c$ of the wavy structures and solitons, both tend to increase as the corrected cometocentric distance dc increases. These results agree with the earlier research from Voelzke and Matsuura
(1998), which analysed comet 1P/Halley's tail structures in its last apparition in 1986.

The opportunity to extensively investigate a bright comet at two consecutive appearances using the wealth of observational information gathered in 1910 and comparing it with the material obtained in 1986, allows a better analysis of cometary evolution, besides being so far a rare opportunity.

The goals of this research are to report the results obtained from the analysis of the 1P/Halley's 1910 II images, to provide empirical data for comparison with an earlier study of comet 1P/Halley in 1985-1986 (VOELZKE; MATSUURA, 1998) and to form the input for future physical/theoretical work.

Observation: This text is a summary of the published work: Morphological Analysis of the Tail Structures of Comet P/Halley 1910 II (VOELZKE; IZAGUIRRE, 2012).

\section{ACKNOWLEDGEMENTS}

The support obtained by L.S.I. from Fundação de Amparo à Pesquisa do Estado de São Paulo, FAPESP, under Grant $02 / 13707-0$ is gratefully acknowledged.

\section{REFERENCES}

BRANDT, J. C.; RANDALL, C. E.; SNOW, M.; YI, Y. Initial overview of disconnection events in Halley's Comet 1986. In: ASTEROIDS, Comets, Meteors 1991. Houston: Lunar and Planetary Institute, LPI, 1992. p. 93-96.

BRANDT, J. C.; SNOW, M. Heliospheric latitude variations of properties of cometary plasma tails: a test of the Ulysses Comet Watch Paradigm. Icarus, v. 148, p. 52-64, 
2000.

DONN, B.; RAHE, J.; BRANDT, J. C. Atlas of Comet Halley 1910 II. Washington: NASA Scientific and Technical Information Branch, 1986. 600 pp. (NASA SP-488).

HYDER, C. L.; BRANDT, J. C.; ROOSEN, R. G. Tail structures far from the head of Comet Kohoutek. I. Icarus, v. 23, p. 601-610, 1974.

JOCKERS, K. The ion tail of Comet Kohoutek 1973 XII during 17 day of solar wind gusts. Astronomy and Astrophysics Supplement Series, v. 62, p. 791-838, 1985.

ROBERTS, B. Solitary waves in a magnetic flux tube. Physics of Fluids, v. 28, n. 11, p. 3280-3286, 1985.

SCHULZ, R.; A'HEARN, M. F.; SAMARASINHA, N.H. Simulation of $\mathrm{CN}$ jets and $\mathrm{CN}$ shells in Comet P/Halley. Bulletin of the American Astronomical Society, v. 24, p. 1004, 1992.

SCHULZ, R., SCHLOSSER, W. CN-shell structures and dynamics of the nucleus of Comet P/Halley. Astronomy and Astrophysics, v. 214, p. 375-385, 1989.

TOMITA, K.; SAITO, T.; MINAMI, S. Structure and dynamics of the plasma tail of Comet P/Halley - part two - kink event on 1986 jan 10-11. Astronomy and Astrophysics, v. 187, p. 215, 1987.

VOELZKE, M. R. Analysis of the plasmacoma of Comet $\mathrm{P} /$ Halley by image processing techniques of Bochum's photoplates. Astronomical Society of the Pacific, v. 108, p. 1063, 1996.

VOELZKE, M. R. Disconnection events in comets. Earth, Moon, and Planets, v. 90, n. 1, p. 405-411, 2002.

VOELZKE, M. R. Disconnection events processes in cometary tails. Earth, Moon, and Planets, v. 97, p. 399-409, 2005.

VOELZKE, M. R.; MATSUURA, O. T. Morphological analysis of the plasma structures of comet P/Halley. Planetary and Space Science, v. 46, n. 8, p. 835-841, 1998.

VOELZKE, M. R.; MATSUURA, O. T. The onsets of disconnection events of comet P/Halley on 1985 December 13-14 and 1986 February 22. Astronomy and Astrophysics Supplement Series, v. 146, p. 1-5, 2000.

VOELZKE, M. R.; IZAGUIRRE, L. S. Morphological Analysis of the Tail Structures of Comet P/Halley 1910 II. Planetary and Space Science, v. 65, p. 104-108, 2012.

VOELZKE, M. R.; SCHLOSSER, W.; SCHMIDT-KALER, T. H. Time analysis of the $\mathrm{CO}^{+}$coma of Comet $\mathrm{P} /$ Halley by image processing techniques. Astrophysics and Space Science, v. 250, p. 35-51, 1997.

YI, Y.; WALKER, R. J.; OGINO, T.; BRANDT, J. C. Reply. Journal of Geophysical Research, v. 103, n. A4, p. 6637-6640, 1998. 